\title{
PENERAPAN PENDEKATAN KI HAJAR DEWANTARA UNTUK MENINGKATKAN HASIL BELAJAR KALOR SISWAKELAS X2 SMA NEGERI 2 BAUBAU
}

\author{
Ummi Salamah \\ SMAN 2 Baubau Sulawesi Tenggara \\ Email: ummibaubau@gmail.com
}

\begin{abstract}
Abstrak
Tujuan penelitian untuk mendeskripsikan hasil belajar siswa materi kalor melalui penerapan pendekatan Ki Hajar Dewantara. Subyek penelitian adalah siswa kelas X2 tahun akademik 2014/2015 SMA Negeri 2 Baubau. Hasil penelitian menunjukkan bahwa penerapan pendekatan Ki Hajar Dewantara dapat meningkatkan hasil belajar siswa kelas X2 SMA Negeri 2 Baubau pada materi kalor. Ketuntasan belajar siswa meningkat dari 0\% (sebelum tindakan) menjadi 60,6\% (siklus I) 72,7\% (siklus II) 84,8\% (siklus III). Rerata nilai siswa meningkat dari 58,45 (sebelum tindakan) menjadi 79,37 (siklus I), 82,59 (siklus II) dan 83,23 (siklus III).
\end{abstract}

\section{Kata kunci: pendekatan Ki Hajar Dewantara-kalor-hasil belajar}

\section{Latar Belakang}

Dalam satu tahun terakhir menunjukkan hasil ulangan harian pelajaran fisika khususnya pada materi kalor diperoleh $40 \%$ sampai $50 \%$ siswa kelas X2 tidak tuntas belajarnya dengan KKM 76 dan observasi yaitu nilai rerata hasil belajar semester genap tahun pelajaran 2014/2015 untuk mata pelajaran Fisika kelas X2 sebesar 58,45 . Penyebabnya antara lain pemahaman konsep matematika siswa masih rendah, seperti: 1) sulitnya memahami perbandingan berbagai skala termometer; 2) pemuaian yang masih sangat konkrit, 3) penerapan Asas Black. Selain itu proses pembelajaran masih menggunakan model pembelajaran konvensional, membuat keaktifan siswa dalam pembelajaran tidak optimal. Guru berupaya agar dalam pembelajaran penting untuk melibatkan semua siswa secara aktif dan menyenangkan sehingga tercipta pembelajaran aktif, inovatif, kreatif, efektif, dan menyenangkan, yang dapat membangun pengetahuannya sendiri berdasarkan pengalaman dari kegiatan yang telah dilakukannya. Salah satu pembelajaran konstruktivisme yang menekankan pengetahuan dibangun oleh siswa secara aktif adalah pendekatan Ki Hajar Dewantara.

Piaget dan Vygotsky dalam Sutiono (2001: 2) menyatakan bahwa belajar tidak hanya sekedar menghafal agar siswa benar-benar memelihara dan menerapkan pengetahuan yang diperolehnya, maka siswa perlu dibiasakan untuk memecahkan masalah, menemukan sesuatu yang berguna dan bergelut dengan ideidenya sendiri, siswa harus mengkonstruksi pengetahuan di dalam benaknya sendiri. Guru dapat memfasilitasi proses tersebut dangan cara: 1) Membuat informasi bermakna dan relevan bagi siswa; 2) Memberi siswa kesempatan menemukan atau menerapkan ide-ide mereka sendiri; 3) Menyadarkan siswa untuk menerapkan strategi mereka sendiri dalam belajar.

Suparno dalam Anonim (2002: 84-85) mengemukakan bahwa salah satu dasar dari paham konstruktivis adalah teori Piaget bahwa anak membangun sendiri skemanya serta membangun konsep-konsep melalui pengalaman-pengalamannya. Perkembangan kognitif sebagian besar bergantung seberapa jauh anak memanipulasi dan aktif berinteraksi dengan lingkungannya. Implikasi dari teori Piaget di dalam paham kontruktivis terletak pada peran guru sebagai fasilitator yang dapat menciptakan lingkungan belajar yang kondusif bagi siswa-siswanya.

Sejalan dengan konstruktivisme, Menurut Ki Hajar Dewantara ada tiga bentuk posisi guru dalam pendidikan ialah Ing Ngarsa Sung Tulada, Ing Madya Mangunkarsa, dan Tut Wuri 
Handayani (Anonim, 2002:473). Tirtahardja dan Sulo, (1994: 117-118) menyebut bahwa azas atau semboyan pendekatan Ki Hajar Dewantara yakni: a) Ing Ngarsa Sung Tulada (Jika di depan, menjadi contoh), b) Ing Madya Mangu Karsa (Jika di tengah-tengah, membangkitkan kehendak, hasrat atau motivasi) dan c) Tut Wuri Handayani (Jika di belakang, mengikuti dengan awas). Langkah-langkah pembelajaran melalui pendekatan Ki Hajar Dewantara dapat dilihat pada Tabel 1 berikut:
Penelitian ini bertujuan untuk mendeskripsikan hasil belajar siswa kelas X2 SMA Negeri 2 Baubau pada materi kalor melalui penerapan pendekatan Ki Hajar Dewantara. Hasil belajar adalah cerminan sejauh mana keberhasilan siswa dalam mengetahui dan memahami suatu materi pembelajaran. (Winkel, 1983: 77). Widjaya (1991: 58-59) mengkategorikan lima jenis hasil belajar yang hendak dicapai meliputi: a) kemampuan intelektual, yaitu kemampuan individu merespons lingkungan.

Tabel 1. Langkah-langkah Pembelajaran Melalui Pendekatan Ki Hajar Dewantara

\begin{tabular}{|c|c|c|}
\hline Tahap & Guru & Siswa \\
\hline $\begin{array}{l}\text { 1. Ing Ngarsa } \\
\text { Sung Tulada }\end{array}$ & $\begin{array}{l}\text { a. Berada di depan } \\
\text { b. Mengajak siswa menemukan persoalan } \\
\text { c. Menyuruh siswa menghubungkan } \\
\text { persoalan dengan pengetahuan yang } \\
\text { telah dimilikinya } \\
\text { d. Membimbing siswa membuat peta } \\
\text { persoalan } \\
\text { e. Membimbing siswa menentukan } \\
\text { persoalan yang akan dikaji } \\
\text { f. Membimbing siswa membuat dugaan } \\
\text { sementara }\end{array}$ & $\begin{array}{l}\text { a. Memperhatikan topik } \\
\text { dan persoalan yang } \\
\text { diutarakan guru } \\
\text { b. Menghubungkan } \\
\text { persoalan dengan } \\
\text { pengetahuan yang } \\
\text { dimilikinya } \\
\text { c. Membuat peta } \\
\text { persoalan dan } \\
\text { keterkaitan antar factor }\end{array}$ \\
\hline $\begin{array}{l}\text { 2. Ing Madya } \\
\text { Mangunkarsa }\end{array}$ & $\begin{array}{l}\text { a. } \\
\text { persama-sama siswa merumuskan } \\
\text { b. Membantu siswa merancang kegiatan } \\
\text { pembuktian } \\
\text { c. Membantu siswa menyediakan alat dan } \\
\text { bahan yang dibutuhkan untuk kegitan } \\
\text { pembuktian } \\
\text { d. Membimbing siswa melakukan } \\
\text { pembuktian } \\
\text { e. Membimbing siswa melakukan } \\
\text { pengukuran }\end{array}$ & $\begin{array}{l}\text { a. Menentukan persoalan } \\
\text { yang akan dikaji dalam } \\
\text { kelompok kecil } \\
\text { b. Membuat dugaan akan } \\
\text { jawaban persoalan } \\
\text { tersebut } \\
\text { c. Merancang kegiatan } \\
\text { pembuktian } \\
\text { d. Melakukan pembuktian } \\
\text { e. Mengumpulkan data } \\
\text { f. Mengorganisasi dan } \\
\text { memaknakan data }\end{array}$ \\
\hline $\begin{array}{l}\text { 3. Tut Wuri Han- } \\
\text { dayani }\end{array}$ & $\begin{array}{l}\text { a. Membimbing siswa dalam } \\
\text { konseptualisasi } \\
\text { b. Menjadi "moderator" diskusi kelas } \\
\text { c. Memberi klarifikasi konsep } \\
\text { d. Memberi pengayaan }\end{array}$ & $\begin{array}{l}\text { a. Siswa tampil ke depan } \\
\text { b. Diskusi hasil kegiatan } \\
\text { c. Persentase hasil secara } \\
\text { klasikal } \\
\text { d. Diskusi kelas dan } \\
\text { sharing hasil } \\
\text { e. Refleksi individual } \\
\text { f. Portofolio }\end{array}$ \\
\hline
\end{tabular}


Proses mengerjakan sesuatu menurut jenis kemampuan intelektual tertentu; b) Strategi kognitif, yaitu kemampuan individu dalam mengingat dan berpikir, c) informasi verbal yaitu kemampuan menguasai pengetahuan melalui kata-kata agar individu tersebut sanggup menyebutkannya; d) keterampilan motorik, yaitu kemampuan membuat sketsa, merangkai alat, dan melacak.

\section{Metode Penelitian}

Penelitian ini dilaksanakan di SMA Negeri 2 Baubau yang pelaksanaannya dimulai bulan Februari - April 2015 bertempat di kelas X2 berjumlah 33 siswa, yang melibatkan peneliti sebagai guru dan seorang teman sejawat yang membantu mengambil data (sebagai observer) dalam pelaksanaan penelitian. Penelitian ini merupakan penelitian tindakan kelas yang dilaksanakan dalam tiga siklus. Data yang diperoleh adalah kuantitatif, diperoleh dengan alat evaluasi hasil belajar, dan data kualitatif yang diperoleh melalui jurnal dan hasil observasi. Cara pengambilan data yaitu dari pelaksanaan pembelajaran melalui lembar observasi; data hasil belajar siswa melalui tes hasil belajar siswa dan data refleksi diri diambil dengan menggunakan jurnal. Kemudian dianalisis menggunakan statistik deskriptif untuk memberikan gambaran distribusi aktivitas dan hasil belajar siswa yang diajar dengan menggunakan pendekatan Ki Hajar Dewantara.
Langkah-langkah menganalisis data hasil belajar siswa: (1) menentukan hasil belajar siswa, rentang nilai yang digunakan untuk tes obyektif adalah 0 sampai 100 dengan rumus:

$$
X_{i}=\frac{S p i}{S m} x 100
$$

Dengan: $X i=$ Nilai yang diperoleh siswa ke-I; $S p i=$ Skor yang diperoleh siswa ke-i.; $S m=$ Skor maksimum (Usman dan Setiawati, 2001); (2) menentukan nilai rata-rata hasil belajar siswa dengan rumus:

$$
\bar{x}=\frac{\sum x_{i}}{n} \text { dengan: } \bar{x}=\text { Nilai rata-rata dan }
$$

$\sum x_{i}=$ Jumlah nilai hasil belajar siswa, $\mathrm{i}=1,2,3, \ldots, \mathrm{n} ; \mathrm{n}=$ Jumlah siswa (Sudjana, 1996); (3) menentukan tingkat pencapaian ketuntasan belajar, dengan menggunakan rumus: $\%$ tuntas $=$

$=\frac{\sum f}{n} x 100 \%$ dengan: $\sum f=$ Jumlah siswa tuntas belajar dan $\mathrm{n}=$ Jumlah siswa secara keseluruhan (Sudjana, 2005)

\section{Hasil Penelitian dan Pembahasan}

Materi kalor yang diajarkan pada kelas Siswa Kelas X2 sesuai dengan RPP dengan menggunakan pendekatan Ki Hajar Dewantara sampai tiga siklus, dengan Jadwal Pelaksanaan

\begin{tabular}{|c|c|c|c|}
\hline No. & Jenis Kegiatan & Waktu Pelaksanaan & Keterangan \\
\hline \multirow[t]{3}{*}{1.} & $\begin{array}{l}\text { Tindakan Siklus I } \\
\text { a. Penyajian Kelas } \\
\text { Pertemuan } 1\end{array}$ & Selasa, 24 Pebruari 2015 & $3 \times 45$ menit \\
\hline & $\begin{array}{l}\text { b. Penyajian Kelas } \\
\text { Pertemuan } 2\end{array}$ & Selasa, 3 Maret 2015 & $3 \times 45$ menit \\
\hline & $\begin{array}{l}\text { c. Tes Tindakan } \\
\text { Siklus I }\end{array}$ & Selasa, 10 Maret 2015 & $3 \times 45$ menit \\
\hline \multirow[t]{2}{*}{2.} & $\begin{array}{l}\text { Tindakan Siklus II } \\
\text { a. Penyajian Kelas } \\
\text { Pertemuan } 3\end{array}$ & Selasa, 17 Maret 2015 & $3 \times 45$ menit \\
\hline & $\begin{array}{l}\text { b Tes Tindakan } \\
\text { Siklus II }\end{array}$ & Selasa, 24 Maret 2015 & $3 \times 45$ menit \\
\hline
\end{tabular}
Penelitian yaitu: 


\begin{tabular}{|c|c|c|c|}
\hline No. & Jenis Kegiatan & Waktu Pelaksanaan & Keterangan \\
\hline \multirow[t]{3}{*}{3.} & Tindakan Siklus III & & \\
\hline & $\begin{array}{l}\text { a Penyajian Kelas } \\
\text { Pertemuan } 4\end{array}$ & Selasa, 31 Maret 2015 & $3 \times 45$ menit \\
\hline & $\begin{array}{ll}\text { b } & \text { Tes Tindakan } \\
& \text { Siklus III }\end{array}$ & Selasa, 7 April 2015 & $3 \times 45$ menit \\
\hline
\end{tabular}

Prosedur penelitian tindakan kelas ini dapat dijabarkan sebagai berikut:

\section{Siklus Pertama}

a. Perencanaan Tindakan

Kegiatan pada tahap ini adalah: (a) Guru dan observer menetapkan alternatif tindakan terhadap permasalahan pembelajaran pada kelas X2 SMA Negeri 2 Baubau; (b) membuat RPP-01 dan skenario pembelajaran siklus I dengan pendekatan Ki Hajar Dewantara; (c) Membuat LKS01 dan menyiapkan peralatan dan bahan untuk kegiatan eksperimen; (d) Membuat lembar pengamatan aktivitas belajar siswa dan lembar observasi kegiatan guru; (e) Membuat alat evaluasi berupa tes hasil belajar (soal tes tindakan) pada siklus I, dan kunci jawaban serta aturan penskoran.

b. Pelaksanaan Tindakan

Kegiatan pada tahap ini adalah: peneliti melaksanakan kegiatan pembelajaran dengan penerapan pendekatan Ki Hajar Dewantara pada materi pokok kalor sesuai RPP-01 dan skenario pembelajaran untuk pertemuan pertama dan kedua.

c. Observasi dan Evaluasi

Kegiatan pada tahap ini adalah mengamati pelaksanaan tindakan siklus I dengan menggunakan lembar pengamatan aktivitas siswa dan guru selama kegiatan pembelajaran, disamping hal tersebut guru melakukan evaluasi kepada siswa untuk mengetahui hasil belajar dengan memberikan tes hasil belajar siklus I dalam bentuk tes essay sebanyak 5 nomor.

d. Refleksi

Kegiatan pada tahap ini adalah untuk memantau dan menilai seberapa jauh keterlaksanaan proses pembelajaran yang telah dirancang dalam RPP 01, yang dilakukan terhadap seluruh hasil observasi, untuk menentukan tindakan pada tahap berikutnya.

\section{Siklus Kedua}

a. Perencanaan Tindakan

Kegiatan pada tahap ini adalah: Guru dan observer menetapkan alternatif tindakan terhadap permasalahan pembelajaran pada kelas X2 SMA Negeri 2 Baubau; (b) membuat RPP-02 dan skenario pembelajaran II dengan tahap pendekatan Ki Hajar Dewantara; (c) Membuat LKS02 dan menyiapkan peralatan dan bahan untuk kegiatan eksperimen; (d) Membuat lembar pengamatan aktivitas belajar siswa dan lembar observasi kegiatan guru; (e) Membuat alat evaluasi berupa tes hasil belajar (soal tes tindakan) pada siklus II, dan kunci jawaban serta aturan penskoran.

b. Pelaksanaan Tindakan

Kegiatan pada tahap ini adalah guru melaksanakan kegiatan pembelajaran dengan penerapan pendekatan Ki Hajar Dewantara pada materi kalor sesuai dengan RPP-02 dan skenario pembelajaran untuk pertemuan ketiga.

c. Observasi dan evaluasi

Kegiatan pada tahap ini, Observasi dilaksanakan terhadap pelaksanaan tindakan siklus II oleh observer yang dimaksudkan untuk mendapatkan data berupa aktivitas siswa dan guru selama kegiatan pembelajaran. Evaluasi pada akhir siklus II dilakukan kepada siswa untuk mengetahui hasil belajar dengan memberikan tes hasil belajar siklus II dalam bentuk tes essay sebanyak 5 nomor. 
d. Refleksi

Kegiatan pada tahap ini adalah untuk memantau dan menilai seberapa jauh keterlaksanaan proses pembelajaran yang telah dirancang dalam RPP 02. Refleksi dilakukan terhadap seluruh hasil observasi, untuk menentukan tindakan pada tahap berikutnya.

\section{Siklus Ketiga}

a. Perencanaan Tindakan

Kegiatan pada tahap ini adalah: Guru dan observer menetapkan alternatif tindakan terhadap permasalahan pembelajaran pada kelas X2 SMA Negeri 2 Baubau; (b) membuat RPP-03 dan skenario pembelajaran III dengan tahap pendekatan Ki Hajar Dewantara; (c) Membuat LKS03 dan menyiapkan peralatan dan bahan untuk kegiatan eksperimen; (d) Membuat lembar pengamatan aktivitas belajar siswa dan lembar observasi kegiatan guru; (e) Membuat alat evaluasi berupa tes hasil belajar (soal tes tindakan) pada siklus III, dan kunci jawaban aturan penskoran.

b. Pelaksanaan Tindakan

Kegiatan pada tahap ini adalah guru melaksanakan kegiatan pembelajaran dengan penerapan pendekatan Ki Hajar Dewantara pada materi pokok kalor sesuai dengan RPP 03 dan LKS 3, serta skenario pembelajaran untuk pertemuan keempat.

c. Observasi dan Evaluasi

Dalam tahap ini dilaksanakan observasi dan evaluasi terhadap pelaksanaan tindakan III oleh observer, yang menggunakan lembar pengamatan aktivitas guru dan siswa untuk mendapatkan data aktivitas siswa dan guru selama kegiatan pembelajaran yang akurat dan obyektif. Guru melakukan evaluasi kepada siswa untuk mengetahui hasil belajar dengan memberikan tes hasil belajar siklus III dalam bentuk tes essay sebanyak 5 nomor.

d. Refleksi

Refleksi dimaksudkan untuk memantau dan menilai seberapa jauh keterlaksanaan proses pembelajaran yang telah dirancang dalam RPP 03. Refleksi dilakukan terhadap hasil observasi, untuk menentukan tindakan pada tahap berikutnya.

Kriteria Keberhasilan Tindakan

Pelaksanaan tindakan kelas ini dipandang berhasil apabila secara individu, jika siswa mencapai ketuntasan belajar individu telah mencapai nilai $\geq 76$ (KKM mata pelajaran Fisika kelas $X$ yang ditetapkan sekolah) dan Secara klasikal, jika telah mencapai nilai $\geq 75 \%$ siswa tuntas individu.

\section{Hasil dan Pembahasan \\ Siklus I}

Dari hasil observasi didapatkan hasil pengamatan aktivitas siswa menunjukkan aktivitas siswa dalam setiap siklusnya mengalami peningkatan. Pada siklus I skor rerata aktivitas siswa sebesar 2,67 kategori cukup, artinya setiap kelompok masih terdapat 3-4 siswa yang kurang mampu menerapkan semua aspek yang dinilai. Ada beberapa aspek aktivitas siswa yang memiliki skor rendah di antaranya memperhatikan penjelasan materi yang dikemukakan guru, memperhatikan persoalan/permasalahan yang diutarakan guru, menentukan persoalan yang akan dikaji dalam kelompok kecil, bereksperimen dalam anggota kelompok, mendiskusikan dan menuliskan ide/ pendapat dalam bentuk laporan hasil kegiatan, dan mempresentasikan hasil kegiatan di depan kelas.

Faktor lain seperti siswa masih asing dengan pendekatan pembelajaran Ki Hajar Dewantara yang diterapkan guru. Pendekatan siswa aktif dalam Ki Hajar Dewantara merupakan hal baru, karena mereka cenderung terbiasa dengan pembelajaran konvensional yang berpusat pada guru. Siswa masih ragu-ragu untuk menanyakan masalah yang belum dipahaminya baik pada teman sekelompoknya maupun pada guru, dan pada saat mempresentasikan jawabannya sebagian kelompok masih terlihat malu-malu dan ragu karena mereka tidak siap untuk mempresentasikan jawabannya.

Aspek yang paling dominan yaitu pada aspek siswa memperhatikan topik yang diutarakan 
guru sebesar 3,28; siswa memersentasekan hasil kegiatan di depan kelas sebesar 3,17; siswa memperhatikan penjelasan materi yang dikemukakan guru sebesar 2,94; siswa menentukan persoalan yang akan dikaji dalam kelompok kecil, siswa bereksperimen dalam anggota kelompok, serta siswa mendiskusikan dan menuliskan ide/pendapat dalam bentuk laporan hasil kegiatan sebesar 2,86 dan yang terakhir adalah siswa memperhatikan persoalan/permasalahan yang diutarakan guru sebesar 2,81.

\section{Aktivitas Guru Selama Pembelajaran}

Berdasarkan observasi pelaksanaan pembelajaran siklus I pertemuan I menunjukkan bahwa pembelajaran yang dilakukan dengan pendekatan Ki Hajar Dewantara belum sempurna, belum sesuai dengan RPP 01 yang telah disusun dan disepakati antara guru dan observer. Pada kegiatan awal guru tidak menyampaikan pendekatan pembelajaran yang digunakan sehingga siswa kebanyakan terlihat bingung, pada kegiatan inti, guru tidak membimbing kelompok siswa secara menyeluruh dalam mengarahkan soal LKS 01 sehingga banyak kelompok siswa yang bertanya pada kelompok lain dan guru masih mengalami kelemahan pada keterampilan bertanya, memancing hipotesis siswa. Pada kegiatan akhir, guru belum mampu mengorganisasikan waktu yang terlihat dari bertambahnya waktu yang digunakan selama 10 menit dan guru mengajar sesuai RPP 01 tetapi belum secara sistematis.

Pada pertemuan II, kegiatan inti guru mulai membimbing kelompok siswa secara menyeluruh dalam mengerjakan soal LKS 01. Pada kegiatan akhir guru belum mampu mengorganisasikan waktu yang terlihat bertambahnya waktu pembelajaran selama 5 menit dan guru mengajar sesuai RPP 01 dan sistematis.

Adapun hasil refleksi dari siklus I yaitu: (a) Guru kurang memberi umpan balik untuk mengukur pemahaman siswa pada saat menjelaskan materi pembelajaran; (b) Guru kurang memberi petunjuk yang jelas sehubungan dengan kegiatan yang akan dikerjakan siswa dalam
LKS 01; (c) Guru tidak membimbing kelompok siswa secara menyeluruh dalam kegiatan LKS; dan (d) Guru belum bisa mengorganisasikan waktu dengan baik, hal ini terlihat dari bertambahnya waktu yang dibutuhkan.

Untuk mengatasi rendahnya aktivitas siswa pada siklus I, guru dan observer melakukan analisis dan refleksi terhadap faktor-faktor yang menyebabkan rendahnya aktivitas siswa maupun aktivitas guru dalam pembelajaran dan disepakati adanya beberapa kelemahan guru dalam pengelolaan pembelajaran dengan pendekatan Ki Hajar Dewantara di kelas khususnya materi pokok kalor, yakni: (1) Guru kurang memberi umpan balik pertanyaan guna memeriksa pemahaman siswa pada saat menjelaskan materi pelajaran; (2) Guru kurang memberi petunjuk yang jelas sehubungan dengan kegiatan yang akan dikerjakan oleh siswa dalam LKS; (3) Guru tidak membimbing kelompok siswa secara menyeluruh dalam kegiatan LKS; (4) Guru belum bisa mengorganisasikan waktu dengan baik. Hal ini terlihat dari bertambahnya waktu yang dibutuhkan.

Dengan hasil refleksi tersebut, kemudian ditentukan langkah-langkah perbaikan untuk siklus II, yaitu: (1) Guru hendaknya selalu memberi umpan balik pertanyaan guna memeriksa pemahaman siswa pada saat menjelaskan materi pelajaran; (2) Sebelum memberikan kegiatan, hendaknya guru memberi petunjuk yang jelas sehubungan dengan kegiatan yang akan dikerjakan oleh siswa dalam LKS, agar seluruh siswa dapat mengerti maksud dari kegiatan yang akan dilakukan; (3) Dalam memberikan bimbingan, hendaknya guru mengutamakan kelompok siswa yang mengalami kesulitan dalam menyelesaikan kegiatannya; (4) Guru hendaknya mampu mengelola waktu dengan baik dalam pembelajaran.

Berdasarkan hasil evaluasi dan refleksi diatas, guru melakukan perbaikan-perbaikan yang akan diterapkan pada siklus II serta memperbaharui cara menyampaikan materi pelajaran selama ini dengan melibatkan siswa dalam pembelajaran tersebut akan merangsang daya nalar siswa. 


\section{Siklus II}

Aktivitas siswa pada siklus II menunjukkan adanya peningkatan yang signifikan dari siklus I. Hal ini sebagaimana terlihat pada tabel 3, menunjukkan skor rerata sebesar 3,07 dengan kategori baik, dalam arti bahwa pada tindakan siklus II rerata setiap kelompok masih terdapat 1-2 siswa yang kurang mampu menerapkan semua aspek yang dinilai. Peningkatan rerata aktivitas siswa menandakan bahwa siswa suda mulai aktif dalam mengikuti pembelajaran dengan pendekatan Ki Hajar Dewantara.

Di samping itu pula adanya motivasi serta minat belajar siswa yang tinggi, disebabkan karena keterampilan guru memotivasi siswa dengan memberikan nilai dan reword kepada kelompok yang kinerjanya bagus dan kepada siswa yang mempunyai hasil belajar yang tinggi pada setiap siklus. Peningkatan aktivitas belajar siswa tersebut juga dipengaruhi oleh adanya kemampuan guru dalam mengelola pembelajaran dengan pendekatan Ki Hajar Dewantara.

Adanya motivasi dan minat belajar siswa yang tinggi tersebut, disebabkan karena dalam pendekatan Ki Hadjar Dewantara siswa dituntut untuk dapat mengonstruksi pengetahuannya sendiri dengan memperhatikan pengalaman dan konsepsi awal siswa serta berdasarkan penyelidikan yang mereka lakukan melalui kegiatan eksperimen secara langsung.

Berdasarkan hasil evaluasi dan refleksi terhadap siklus II antara guru dengan observer disepakati beberapa perbaikan sebagai penekanan terhadap aktivitas guru dalam mengelola pembelajaran pendekatan Ki Hajar Dewantara pada siklus II yaitu: (1) Pola bimbingan yang digunakan pada siklus II sebaiknya ditingkatkan pada siklus berikutnya yaitu mengutamakan memberikan bimbingan/dorongan kepada siswa yang mengalami kesulitan dalam menyelesaikan kegiatan belajarnya; (2) Pengaturan waktu dan bimbingan guru yang ketat dapat memacu semangat siswa untuk bekerja secara kooperatif dalam kelompok untuk menyelesaikan tugas yang diberikan; (3) Diskusi secara klasikal sangat diperlukan untuk memantapkan penguasaan konsep serta melatih keterampilan siswa dalam mengajukan pertanyaan dan menjawab/merespons pertanyaan siswa dan guru; (4) Pada siklus II guru sudah mampu mengontrol pelaksanaan setiap tahapan pembelajaran. Aspek lain yang diamati pada aktivitas guru adalah penampilan yang sudah relatif tenang dan sudah memberikan batasan yang tegas dan jelas dalam membimbing setiap kelompok siswa, guru juga memberikan kesempatan kepada siswa dalam menarik kesimpulan, sehingga bukan saja guru yang aktif tetapi siswa pun sudah ambil bagian dalam kegiatan pembelajaran. Pada kegiatan akhir, pengorganisasian waktu telah sesuai dengan alokasi waktu yaitu 3 X 45 menit.

Catatan penting dari siklus II ini adalah: (a) Pola bimbingan yang digunakan sebaiknya ditingkatkan pada siklus berikutnya yaitu mengutamakan memberikan bimbingan/ dorongan kepada kelompok siswa yang mengalami kesulitan dalam menyelesaikan kegiatan; b) Pengaturan waktu dan bimbingan guru yang ketat dapat memacu semangat siswa untuk bekerja secara kooperatif dalam kelompoknya untuk menyelesaikan tugas yang diberikan; dan (c) Diskusi secara klasikal sangat diperlukan untuk memantapkan penguasaan konsep serta dapat melatih keterampilan siswa dalam mengajukan pertanyaan dan menjawab/ merespon pertanyaan siswa dan guru.

\section{Siklus III}

Aktivitas siswa siklus III menunjukkan adanya peningkatan yang sangat signifikan dari siklus I dan siklus II. Hal ini sebagaimana terlihat pada Tabel menunjukkan skor rerata aktivitas siswa sebesar 3,17 dengan kategori baik dalam arti bahwa pada siklus III rerata setiap kelompok masih terdapat 1-2 siswa yang kurang mampu menerapkan semua aspek yang dinilai. Tetapi peningkatan rerata aktivitas siswa yang menandakan bahwa siswa mulai aktif dalam mengikuti pembelajaran dengan pendekatan Ki Hajar Dewantara.

Disamping itu pula adanya motivasi serta minat belajar siswa yang tinggi, disebabkan karena keterampilan guru memotivasi siswa dengan memberikan nilai dan reward kepada kelompok yang kinerjanya bagus dan kepada siswa yang mempunyai hasil belajar yang 
tinggi pada setiap siklus. Peningkatan aktivitas belajar siswa tersebut juga dipengaruhi oleh adanya kemampuan guru dalam mengelola pembelajaran dengan pendekatan Ki Hajar Dewantara.

Adanya motivasi dan minat belajar siswa yang tinggi disebabkan karena dalam pendekatan Ki Hajar Dewantara siswa dituntut dapat mengonstruksi pengetahuannya sendiri dengan memperhatikan pengalaman dan konsep awal siswa berdasarkan penyelidikan mereka lakukan melalui kegiatan pengamatan/ eksperimen secara langsung.

Hal ini sebagaimana wawancara yang dilakukan guru (peneliti) dengan beberapa orang siswa di kelas X2 pada akhir pembelajaran, rata-rata dari mereka menyukainya proses pembelajaran dengan pendekatan Ki Hajar Dewantara sangat bagus dan menyenangkan, dimana mereka yang melakukan sendiri kegiatan eksperimen secara langsung dan pengalaman serta pemahaman merupakan kunci untuk mengembangkan suatu ide/gagasan.

Peningkatan rerata aktivitas siswa pada setiap siklus tersebut menandakan bahwa siswa aktif dalam mengikuti pembelajaran. Hasil observasi yang dilakukan guru menunjukkan bahwa pelaksanaan pembelajaran dengan penerapan pendekatan Ki Hajar Dewantara dapat memberikan hasil yang lebih baik.

Pada siklus III penerapan pendekatan Ki Hajar Dewantara semakin baik lagi dibandingkan dengan siklus I dan siklus II. Semua tahapan pada skenario pembelajaran telah dilaksanakan guru dengan baik. Aktivitas siswa dalam pembelajaran juga semakin baik dan stabil. Semangat dan antusias siswa dalam belajar ditunjukkan dengan semakin banyak siswa melaksanakan aspek yang diamati. Adapun hasil analisis dan refleksi pada siklus III yaitu bahwa guru telah mengefektifkan pemantauan dan bimbingan pada seluruh siswa. Semua siswa bersemangat mengikuti pelajaran dan memperhatikan guru.

Analisis deskriptif terhadap aktivitas siswa pada setiap siklus menunjukkan bahwa penerapan pendekatan Ki Hajar Dewantara mampu meningkatkan aktivitas belajar siswa sehingga tampak bahwa pembelajaran yang dilakukan dalam pembelajaran ini lebih terpusat pada siswa (student centre), dimana peran guru dalam pembelajaran hanya bersifat sebagai fasilitator dan mediator. Untuk lebih jelasnya dapat dilihat dalam tabel berikut:

Tabel 2 Data Aktivitas Siswa per Siklus

\begin{tabular}{llccc}
\hline \multirow{2}{*}{ No. } & \multicolumn{1}{c}{ Aspek yang Dinilai } & \multicolumn{3}{c}{ SIKLUS } \\
\cline { 3 - 5 } & \multicolumn{1}{c}{ I } & II & III \\
\hline 1. & Siswa memperhatikan topik yang diutarakan guru. & 3 & 3,17 & 3,67 \\
\hline 2. & $\begin{array}{l}\text { Siswa memperhatikan penjelasan materi yang dikemukakan } \\
\text { guru. }\end{array}$ & 2,83 & 3 & 3 \\
\hline 3. & $\begin{array}{l}\text { Siswa memperhatikan persoalan/ permasalahan yang } \\
\text { diutarakan guru. }\end{array}$ & 2.42 & 3 & 3 \\
\hline 4. & $\begin{array}{l}\text { Siswa menentukan persoalan yang akan dikaji dalam } \\
\text { kelompok kecil }\end{array}$ & 2.58 & 3 & 3 \\
\hline 5. & Siswa bereksperimen dalam anggota kelompok & 2,58 & 3 & 3 \\
\hline 6. & $\begin{array}{l}\text { Siswa mendiskusikan dan manuliskan ide/pendapat dalam } \\
\text { bentuk laporan hasil kegiatan. }\end{array}$ & 2,58 & 3 & 3 \\
\hline 7. & Siswa mempresentasekan hasil kegiatan di depan kelas. & 2,67 & 3 & 3 \\
\hline Rerata Aktivitas Siswa pada setiap Siklus & 2,67 & 3,07 & 3,17 \\
\hline Kategori & Cukup & Baik & Baik \\
\hline
\end{tabular}


Tabel 3. Rerata Aktivitas pada ke-i

\begin{tabular}{|c|c|c|c|c|c|c|}
\hline \multirow[b]{2}{*}{ No } & \multirow[b]{2}{*}{ Indikator } & \multicolumn{3}{|c|}{ Siklus } & \multirow{2}{*}{$\begin{array}{c}\text { Rerata } \\
\text { Aktivitas } \\
\text { pada ke-i }\end{array}$} & \multirow[b]{2}{*}{ Ket. } \\
\hline & & I & II & III & & \\
\hline 1 & $\begin{array}{l}\text { Siswa memperhatikan topik yang diutarakan } \\
\text { guru. }\end{array}$ & 3 & 3,17 & 3,67 & 3,28 & Baik \\
\hline 2 & $\begin{array}{l}\text { Siswa memperhatikan penjelasan materi yang } \\
\text { dikemukakan guru. }\end{array}$ & 2,82 & 3 & 3 & 2,94 & Cukup \\
\hline 3 & $\begin{array}{l}\text { Siswa memperhatikan persoalan/ } \\
\text { permasalahan yang diutarakan guru. }\end{array}$ & 2,42 & 3 & 3 & 2,81 & Cukup \\
\hline 4 & $\begin{array}{l}\text { Siswa menentukan persoalan yang akan dikaji } \\
\text { dalam kelompok kecil. }\end{array}$ & 2,58 & 3 & 3 & 2,86 & Cukup \\
\hline 5 & $\begin{array}{l}\text { Siswa bereksperimen dalam anggota } \\
\text { kelompok. }\end{array}$ & 2,58 & 3 & 3 & 2,86 & Cukup \\
\hline 6 & $\begin{array}{l}\text { Siswa mendiskusikan dan menuliskan ide/ } \\
\text { pendapat dalam bentuk laporan hasil kegiatan. }\end{array}$ & 2,58 & 3 & 3 & 2,86 & Cukup \\
\hline 7 & $\begin{array}{l}\text { Siswa mempresentasekan hasil kegiatan di } \\
\text { depan kelas. }\end{array}$ & 2,67 & 3,33 & 3,5 & 3,17 & Baik \\
\hline
\end{tabular}

\section{Hasil Belajar}

Dari analisis deskriptif diperoleh hasil belajar pada siklus I diperoleh nilai minimum 68,42 dan maksimum 96,49 dengan rerata 79,37 terdapat 20 orang siswa tuntas belajar $(60,61 \%)$ dan 13 siswa tidak tuntas belajar (39,39\%). Siklus II nilai minimum 71,43 dan maksimum 96,94 dengan rerata 82,59 terdapat 24 orang siswa tuntas belajar $(72,73 \%)$ dan 9 orang siswa tidak tuntas belajar $(27,27 \%)$. Pada siklus III nilai minimum 72,73 dan maksimum 96,59 dengan rerata 83,23 terdapat 28 orang siswa sudah tuntas belajar $(84,85 \%)$ dan 5 orang siswa yang belum tuntas belajar (15,15\%).

Untuk mengetahui sejauh mana pemahaman siswa selama kegiatan belajar-mengajar dengan pendekatan Ki Hajar Dewantara, maka pada akhir kegiatan tatap muka yaitu pada pertemuan ketiga, guru melakukan evaluasi kepada siswa melalui tes hasil belajar siklus II dengan menggunakan tes essay sebanyak 5 nomor pada topik Perpindahan Kalor. Berdasarkan hasil belajar siklus II diperoleh nilai tes hasil belajar tutas sebesar $72,7 \%$ (24 orang) dan sisanya sebesar $27,3 \%$ (9 orang) belum tuntas dengan $K K M \geq 76$. sehingga pada pelaksanaan tindakan siklus II dikategorikan telah mencapai target dan memenuhi ketuntasan belajar namun penelitian masih tetap berlanjut pada siklus III.

Selanjutnya untuk mengetahui sejauh mana pemahaman siswa selama kegiatan belajarmengajar dengan pendekatan $\mathrm{Ki}$ Hajar Dewantara, maka pada akhir kegiatan tatap muka yaitu pada pertemuan keempat, guru melakukan evaluasi kepada siswa melalui tes hasil belajar siklus III dengan menggunakan tes essay sebanyak 5 nomor pada topik Asas Black. Berdasarkan tes hasil belajar siklus III diperoleh nilai tes yang mengalami peningkatan. Dari sebanyak 33 siswa kelas X2. ternyata sebesar $84,8 \%$ (28 orang) telah tuntas belajarnya dan sisanya sebesar 15,2\% (5 orang) belum tuntas belajarnya dengan KKM $\geq 76$. sehingga pada pelaksanaan tindakan siklus III ini dikategorikan telah mencapai target dan memenuhi ketuntasan belajar, maka pelaksanaan tindakan dinyatakan sudah berhasil dan pelaksanaan tindakan telah selesai. Siklus III dengan topik Asas Black menunjukkan adanya peningkatan penguasaan siswa terhadap materi pokok kalor setelah diajarkan dengan pendekatan Ki Hajar Dewantara. Namun masih ada beberapa siswa yang belum mencapai ketuntasan belajar disebabkan karena masih adanya siswa yang belum memahami operasi matematika dengan baik. Adapun hasil analisis 
dan refleksi pada siklus III antara guru dengan observer yaitu bahwa guru telah mengefektifkan pemantauan dan bimbingan pada seluruh siswa. Semua siswa bersemangat mengikuti pelajaran dan memperhatikan guru. Peningkatan aktivitas tersebut, menunjukkan adanya minat dan antusias siswa dalam mengikuti pembelajaran pada meteri pokok Kalor dengan penerapan pendekatan Ki Hajar Dewantara. Untuk lebih jelasnya dapat dilihat dalam tabel berikut:

Tabel 3: Deskripsi hasil belajar siswa setiap siklus

\begin{tabular}{|c|c|c|c|c|c|c|c|c|}
\hline Kelompok & No. & $\begin{array}{l}\text { Nama } \\
\text { Siswa }\end{array}$ & Siklus I & Ket & $\begin{array}{c}\text { Siklus } \\
\text { II }\end{array}$ & Ket & $\begin{array}{l}\text { Siklus } \\
\text { III }\end{array}$ & Ket \\
\hline \multirow{6}{*}{ I } & 1 & FHR & 85,96 & $\mathrm{~T}$ & 89,8 & $\mathrm{~T}$ & 80,68 & $\mathrm{~T}$ \\
\hline & 2 & RZR & 80,7 & $\mathrm{~T}$ & 85,71 & $\mathrm{~T}$ & 90,91 & $\mathrm{~T}$ \\
\hline & 3 & FRN & 78,95 & $\mathrm{~T}$ & 73,47 & TT & 93,18 & $\mathrm{~T}$ \\
\hline & 4 & IKR & 72,81 & TT & 75,51 & TT & 84,09 & $\mathrm{~T}$ \\
\hline & 5 & DND & 85,96 & $\mathrm{~T}$ & 81,63 & $\mathrm{~T}$ & 90,91 & $\mathrm{~T}$ \\
\hline & 6 & DI & 77,19 & $\mathrm{~T}$ & 73,47 & TT & 86,36 & $\mathrm{~T}$ \\
\hline \multirow{5}{*}{ II } & 7 & $\mathrm{AR}$ & 87,72 & $\mathrm{~T}$ & 87,76 & $\mathrm{~T}$ & 96,59 & $\mathrm{~T}$ \\
\hline & 8 & RA & 92,98 & $\mathrm{~T}$ & 93,88 & $\mathrm{~T}$ & 84,09 & $\mathrm{~T}$ \\
\hline & 9 & MRN & 90,35 & $\mathrm{~T}$ & 85,71 & $\mathrm{~T}$ & 81,82 & $\mathrm{~T}$ \\
\hline & 10 & MLT & 78,07 & $\mathrm{~T}$ & 89,8 & $\mathrm{~T}$ & 80,68 & $\mathrm{~T}$ \\
\hline & 11 & $\mathrm{AY}$ & 68,42 & TT & 71,43 & TT & 72,73 & TT \\
\hline \multirow{5}{*}{ III } & 12 & AHS & 96,49 & $\mathrm{~T}$ & 96,94 & $\mathrm{~T}$ & 81,82 & $\mathrm{~T}$ \\
\hline & 13 & SFT & 82,46 & $\mathrm{~T}$ & 79,59 & $\mathrm{~T}$ & 82,95 & $\mathrm{~T}$ \\
\hline & 14 & FAT & 72,81 & TT & 89,8 & $\mathrm{~T}$ & 90,91 & $\mathrm{~T}$ \\
\hline & 15 & SCA & 93,86 & $\mathrm{~T}$ & 86,73 & $\mathrm{~T}$ & 84,09 & $\mathrm{~T}$ \\
\hline & 16 & SSS & 83,33 & $\mathrm{~T}$ & 80,61 & $\mathrm{~T}$ & 81,82 & $\mathrm{~T}$ \\
\hline \multirow{5}{*}{ IV } & 17 & NVR & 85,96 & $\mathrm{~T}$ & 87,76 & $\mathrm{~T}$ & 96,59 & $\mathrm{~T}$ \\
\hline & 18 & HJR & 84,21 & $\mathrm{~T}$ & 85,71 & $\mathrm{~T}$ & 81,82 & $\mathrm{~T}$ \\
\hline & 19 & ALD & 71,93 & TT & 87,76 & $\mathrm{~T}$ & 84,09 & $\mathrm{~T}$ \\
\hline & 20 & FNT & 71,05 & TT & 81,63 & $\mathrm{~T}$ & 73,86 & TT \\
\hline & 21 & YNT & 68,42 & TT & 73,47 & TT & 86,36 & $\mathrm{~T}$ \\
\hline \multirow{6}{*}{$\mathrm{V}$} & 22 & ARV & 93,86 & $\mathrm{~T}$ & 95,92 & $\mathrm{~T}$ & 84,09 & $\mathrm{~T}$ \\
\hline & 23 & HRS & 77,19 & $\mathrm{~T}$ & 83,67 & $\mathrm{~T}$ & 77,27 & $\mathrm{~T}$ \\
\hline & 24 & RST & 70,18 & TT & 75,51 & TT & 72,73 & TT \\
\hline & 25 & FDL & 78,07 & $\mathrm{~T}$ & 81,63 & $\mathrm{~T}$ & 78,41 & $\mathrm{~T}$ \\
\hline & 26 & NRY & 70,18 & TT & 82,65 & $\mathrm{~T}$ & 76,14 & $\mathrm{~T}$ \\
\hline & 27 & PAF & 70,18 & TT & 71,43 & TT & 86,36 & $\mathrm{~T}$ \\
\hline \multirow{6}{*}{ VI } & 28 & ERN & 81,58 & $\mathrm{~T}$ & 81,63 & $\mathrm{~T}$ & 84,09 & $\mathrm{~T}$ \\
\hline & 29 & LLN & 70,18 & TT & 71,43 & TT & 86,36 & $\mathrm{~T}$ \\
\hline & 30 & CHR & 84,21 & $\mathrm{~T}$ & 81,63 & $\mathrm{~T}$ & 81,82 & $\mathrm{~T}$ \\
\hline & 31 & SYM & 70,18 & TT & 81,63 & $\mathrm{~T}$ & 75 & $\mathrm{TT}$ \\
\hline & 32 & SFL & 71,93 & TT & 72,45 & TT & 73,86 & TT \\
\hline & & FBR & 71,93 & TT & 87,76 & $\mathrm{~T}$ & 84,09 & $\mathrm{~T}$ \\
\hline
\end{tabular}




\begin{tabular}{|c|c|c|c|c|c|c|c|}
\hline Kelompok No. & $\begin{array}{l}\text { Nama } \\
\text { Siswa }\end{array}$ & Siklus I & Ket & $\begin{array}{c}\text { Siklus } \\
\text { II }\end{array}$ & Ket & $\begin{array}{l}\text { Siklus } \\
\text { III }\end{array}$ & Ket \\
\hline Jumlah Nilai & & 2619 & & 2726 & & 2747 & \\
\hline Rata-Rata Nilai & & 79,37 & & 82,59 & & 83,23 & \\
\hline Nilai Terendah & & 68,42 & & 71,43 & & 72,73 & \\
\hline Nilai Tertinggi & & 96,49 & & 96,94 & & 96,59 & \\
\hline Jumlah Tuntas & & & 20 & & 24 & & 28 \\
\hline $\begin{array}{l}\text { Jumlah Tidak } \\
\text { Tuntas }\end{array}$ & & & 13 & & 9 & & 5 \\
\hline$\%$ Tuntas & & & 60,6 & & 72,7 & & 84,8 \\
\hline$\%$ Tidak Tuntas & & & 39,4 & & 27,3 & & 15,2 \\
\hline
\end{tabular}

Keterangan: T adalah tuntas dan TT adalah tidak tuntas

Dari hasil penelitian tersebut, ada beberapa kelebihan dan kekurangan pendekatan $\mathrm{Ki}$ Hajar Dewantara yang digunakan. Kelebihankelebihan pendekatan Ki Hajar Dewantara adalah: (1) membiasakan siswa belajar aktif dan mandiri dalam memecahkan suatu persoalan/ masalah yang mampu mengurangi dominasi guru dalam pembelajaran sehingga berdampak pada meningkatnya hasil belajar siswa khususnya pada materi kalor; (2) menciptakan situasi belajar terbuka dan memberi kebebasan pada siswa dalam mengemukakan ide atau gagasannya serta memberi kesempatan kepada siswa untuk bertanya secara bebas dengan teman dan guru; (3) menciptakan kreativitas siswa untuk belajar sehingga suasana kelas lebih nyaman dan kreatif, terjalin kerjasama sesama siswa, dan siswa terlibat langsung dalam melakukan kegiatan; (4) memotivasi siswa untuk belajar baik secara mandiri dan atau kelompok; (5) memberi kemudahan bagi peserta didik dalam melihat kegiatan-kegiatan dan ide-ide beda yang terkait dengan materi; dan (6) menciptakan belajar menjadi bermakna karena timbul kebanggaan siswa menemukan sendiri konsep ilmiah yang sedang dipelajari dan siswa akan bangga dengan hasil temuannya.

Kekurangan pada pendekatan Ki Hajar Dewantara adalah: (1) penggunaan alat-alat yang terbuat dari kaca yang mudah pecah harus berhati-hati karena memerlukan dana yang sangat besar serta penggunaan lampu spiritus harus berhati-hati; (2) guru lebih memusatkan perhatian pada kegiatan dari pada pengembangan konsep; (3) siswa belum terbiasa belajar mandiri atau kelompok akan merasa asing dan sulit menguasai konsep (4) sulitnya guru menerapkan dengan alokasi waktu 2 jam pelajaran.

Berdasarkan hasil analisis berupa aktivitas siswa serta hasil belajar pada materi kalor setelah pemberian tindakan dengan menggunakan pendekatan Ki Hajar Dewantara, diperoleh peningkatan baik rerata aktivitas siswa maupun rerata hasil belajar, sehingga dapat disimpulkan bahwa hipotesis penelitian yang telah dirumuskan sebelumnya dapat diterima.

\section{Penutup \\ Simpulan}

Berdasarkan rumusan masalah dan hasil analisis data penelItian yang dilakukan, maka dapat disimpulkan sebagai berikut:

1. Aktivitas siswa kelas $X 2$ SMA Negeri 2 Baubau dalam proses belajar-mengajar pada setiap siklus meningkat dengan skor rerata aktivitas siswa pada siklus I sebesar 2,67 dengan kategori cukup, pada sisklus II sebesar 3,07 dengan kategori baik, dan pada siklus III sebesar 3,17 dengan kategori baik.

2. Hasil belajar fisika siswa kelas X2 SMA Negeri 2 Baubau pada materi kalor yang diajarkan melalui pendekatan Ki Hajar Dewantara adalah cenderung meningkat, dimana nilai rerata hasil belajar siswa pada siklus I sebesar 79,37, siklus II sebesar 82,59 dan siklus III sebesar 83,23 demikian pula ketuntasan belajar pada siklus I sebesar 
$60,61 \%$ (20 orang), siklus II sebesar 72,73\% (24 orang), dan siklus siklus III sebesar $84,85 \%$ (28 orang).

3. Penerapan pendekatan Ki Hajar Dewantara dapat meningkatkan hasil belajar fisika siswa kelas X2 SMA Negeri 2 Baubau pada materi kalor, dimana penekanan pembelajaran yang optimal adalah pembelajaran yang berpusat pada siswa atau tekanan dalam proses pembelajaran terletak pada partisipasi siswa, pengajar berperan sebagai fasilitator yang membantu siswa mengonstruksi konseptualisasi dan solusi dari masalah yang dihadapi, serta adanya keterampilan guru memotivasi siswa dengan memberikan pujian pada kelompok yang kinerjanya baik dan mempunyai hasil belajar yang tinggi pada setiap siklus.

\section{Saran}

Berdasarkan hasil yang diperoleh dalam penelitian ini maka diajukan beberapa saran berikut: kiranya dapat memahami lagi berbagai pendekatan pembelajaran yang dapat menimbulkan kreativitas siswa yang optimal dalam menemukan sesuatu hal di lingkungan yang berkaitan erat dengan konsep fisika yang diajarkan sehingga siswa benar-benar merasakan manfaat belajar guna meningkatkan hasil belajar fisika.

\section{Daftar Pustaka}

Anonim. (1999). Penelitian Tindakan Kelas. Jakarta: Proyek PGSM Dikti.

Anonim. (2002). National Sciences Education Seminar. Malang: State Universitas of Malang.

Sudjana. (1996). Teknik Analisis Regresi dan Korelasi, Bandung: Tarsito.

Sudjana, (2005). Metode Statistika. Bandung: Tarsito.

Sutiono, (2001). Pembelajaran Kontruksi makalah disajikan pada pelatihan TOT Guru Mata Pelajaran SLTP dari 6 propinsi pada tanggal 20 Juni s.d. 6 Juli. Surabaya.

http://www.aktualpress.com/read/2018/05/03/ metode-pendidikan-ala-ki-hajar- dewantara/ diakses tanggal 3 Mei 2018

http//majalah-pusara.blogspot.com/2007/12/ kontruktivisme-dalam-pemikiran.html. Diakses tanggal 20 Mei 2018.

Tirtarahardja dan Sulo, (1994). Pengantar Pendidikan. Jakarta: P2TK Ditjen Dikti Depdikbud

Usman dan Setiawati, (2001). Upaya Optimalisasi Kegiatan Belajar-Mengajar. Bandung: Remaja Rosdakarya

Widjaya. G, (1991). Kemampuan Guru dalam Proses Belajar-Mengajar. Bandung: Rosdakarya.

Winkel. W.S, (1983). Psikologi Pengajaran. Jakarta: Gramedia. 